\title{
Arabic Dialects and Classical Arabic Language
}

\author{
Abdulhafeth Ali Khrisat \\ Department of English \& Translation, Faulty of Sciences \& Arts/Khulais \\ University of Jeddah, Saudi Arabia \\ Ziad Ali Al-Harthy \\ Department of Arabic Language, Faulty of Sciences \& Arts/Khulais \\ University of Jeddah, Saudi Arabia
}

\begin{abstract}
Classical Arabic (CA) is known as the language of the Qur'an. This form of Arabic language has been used among the people of different tribes of the Arabian Peninsula. Relations between these tribes were based on trade, marriage, war and poetry competition. The speakers of the tribes in Arabia have used different Arabic dialects. However, the dialect of the tribe of Quraish must have been like Classical Arabic. The study aims to prove that these old dialects of these tribes have not become remote and archaic but they have ensured their existence and continued to be used in many parts across the Arab world. Moreover, the article will identify the old different dialects of Arabic language and their characteristics and how they are related to the modern dialects in various Arab regions, with the exception of the arabized and borrowed words. In other words, modern Arabic dialects are rooted in the old dialects of Classical Arabic.
\end{abstract}

Keywords: Arabic Language, Arabic Dialects, Classical Arabic, Arabia, Modern Standard Arabic

\section{INTRODUCTION}

Arabic language has been used in the Arabian Peninsula for at least 2000 years. It dates back to the eighth century BC and the sixth century AD. Fragmentary inscriptions, which were derived from epigraphic South Arabia, are used. This Classical Arabic (CA), the standard poetic language and the language of the Qur'an, which has preserved it throughout centuries, is not necessarily identical with any of these early dialects. It is based on medieval dialects of Arab tribes. Since CA is one of the Semitic languages, Assyria, Hebrew, Akkadin, Aramaic and Amharic, it has noncatentative morphology. Derivatives in Arabic contain the three-letter root, 'fa', 'a', 'la'. According to the grammarians, the root of each word encompasses all actions or objects and all the modified forms of the root are "obtained" or "derived" in some way from it.

Different dialects in the Arab world have their origins in old dialects. Modern Arabic dialects are taught as being isolated and remote from the old ones. In the meantime, many Arab intellectuals attempt to teach these old dialects as some kind of history and that they are irrelevant to the present reality.1 A variety of examples taken from many parts of the Arab world will prove that these old Arabic dialects, excluding the arabized and the borrowed words, are still used in the Arab world and many speakers use these dialects without being aware of the fact that their speeches are rooted in these old dialects. 


\section{Arabic Language And Islam}

The spread of Islam is the main factor that helped Arabic language go beyond the nomadic tribes who first spoke it. The first arabized centers outside the Arabian Peniusula have been established in the seventh and eighth centuries (Donner, 1981, Versteegh, 1997). After the spread of Islam, Arab speakers came into contact with non-Arab population. Bedouin Arabic seems to be different from the urban Arabic.2 All Arabic dialects are based on the Classical language. Regardless of their cultural, linguistic and racial differences, Muslims form one community of believers. Ninety percent of the world's Muslims do not speak Arabic as their native language. Yet in daily prayers, when reading the Qur'an, or even in simple conversations with each other, they speak broken Arabic in heavily accented Arabic, but most Muslims attempt to speak and understand at least some Arabic.

\section{Arabic Language And The Tribe of Quraish}

In the pre-Islamic period, Arabs have lived in different tribes throughout the Arab Peninsula. Every tribe has a title to be known and called by it, like Ghadfan, Hawazen, Bano Abs, Quraish and others. Relations between these tribes have been based on trade, marriage, and war and poetry competition. According to Ibn Faris (1910), Arab linguists, grammarians and narrators of poetry have known and well documented that the most eloquent of Arabic language is the tribe of Quraish among all other Arab tribes. There has been other tribes like Thaqeef and Sa'ad bin Bakr, and others who have not come up to the level of language eloquence as Quraish. The Prophet Mohamed, a descendent of Quraish who has been chosen by Allah [God] to convey the message of Islam to all others, says: "I'm the most eloquent of Arabs, since I'm from Quraish and brought up in Sa'ad bin Bakr" (al-Zamakheri, 1964, 147). The language of the Qur'an was the spoken language of the Prophet, i.e. the dialect of Quraish. The dialect of Quraish must have been like Classical Arabic although some linguists deny this fact by referring to the absence or presence of case endings in the dialect. Quraish valued their genealogical connections with bedouin tribes and were interested in attracting bedouins to their fairs and religious experiences. Therefor "the self-evaluation of the nomad aristocracy was accepted by the towns people to such an extent that they adapted also the language and the poetry which were then cultural badge of honor in that society" (Rabin, 1955, 27).

\section{Arabic Language And Its Dialects}

Old Arabic, a predecessor to Classical Arabic seems to have coexisted with the languages in Central and North Arabia (Woodard, 2008, 80). There are very few differences between Ancient Arabic and Classical Arabic. In the pre-Islamic period, $600 \mathrm{AD}$, poetry was composed and recorded in the Arabic language, which is called "Classical Arabic" (CA). Many linguists try to make differences between CA and what is so-called "Modern Standard Arabic" (MSA). MSA descended from CA.3 These linguists try to define CA as the language found in the Qur'an used from the pre-Islamic Arabia to that of Abbasid Caliphate, whereas MSA is the variety used in most current, printed Arabic publications and high register speech. Classical morphology has fundamental features besides the three-letter, three-sound root for every word, 'fa', 'a', 'la'; a declension system sharing three cases, nominative, accusative and generative; three numbers, the singular, the dual and the plural are used with nouns, verbs and adjectives; and two grammatical genders, masculine and feminine that are distinguished in nouns and adjectives. However, Fischer (1997) believes that the morphology and the syntax of CA and MSA have remained unchanged over the centuries. Habash (2010) states that the MSA is the official language of Arab world and "MSA is syntactically, morphologically, and phonologically based on the Classical Arabic, the language of the Qur'an [Islam's Holy Book]" (my emphasis 12). 
Undoubtedly there is a difference between one dialect and another. In the pre-Islamic period, the difference has been related to the differences between tribes.4 Today the difference is between one region and another. Fischer and Jastrow (1997) remark the exact cause for the rise of Arabic dialects:

One will hardly go wrong if one imagines that the development of New [colloquial] Arabic was connected with dialect mixing in the camps of the conquerors, the influence of the languages and dialects of the conquered, and the formation of regional vernaculars. Later population displacements and the constant leveling tendencies through cross-regional contacts between the cities, likewise tendencies toward peculiar developments among the most isolated rural populations, may have been equally important development factors (Belnap and Haeri, 32).

Brockleman (1916) remarks that modern dialects of Arabic, apart from the arabized and the borrowed, are a direct continuation of an earlier phase of Classical Arabic (41). Arabic language borrows words from other languages for new entities. Modernization involves the creation of new terms for concepts that did not exist in Arabic. Khrisat and Mohamad (2014) confirm that arabization provides Arabic language with new vocabulary and "the arabized and borrowed words play a significant role in enriching Arabic language" (140). Changes have taken place in the switch from Standard Arabic to colloquial Arabic. Ferguson (1959) states that there is an expectation among Arabs that MSA will take over the Arab world (255). Written Arabic is highly lexicalized. One needs to know the words in order to be able to read correctly. Many Arab intellectuals, says Daniels (1996), have proposed changes in order to make Arabic writing system have correspondence between letter and sound.5

Arabic dialects show that they are affected by different factors: mainly which Arab tribe has settled that region, therefore gave it their dialect and which foreign language was the source of loan words; cultural contact, migration patterns and differences between countryside and villages; and the difference between bedouin and sedentary speech. Variable rules of structure were either added, deleted, recorded or invented. Although there is a difference between sedentary (Hijazi) Arabic dialect and bedouin (Tamimi) dialect, Arabic language, according to al-Seyyuti (1998), has been documented, transferred and become a linguistic field of study by Arab linguists and grammarians in Kofa and Basra of Iraq (168).

\section{Arabic Dialects: Types And Characteristics}

al-Seyyuti (1998) mentions that Arabs used to make pilgrimage to Mecca in the pre-Islamic times every year. The Quraish tribe listens to their dialects, tries to select what is appropriate for their usage, and avoids some vocabulary, which is considered to be rude (175). Seebawaih (1977) studies phonemic substitution in relation to morphology, assimilation, and ease of articulation. He presents a number of examples of changing a consonant into another for morphological processes. He mentions that speakers of Classical Arabic tend to change certain consonants to make them similar to juxtaposed consonants for economy of effort and ease of articulation.6 The voiceless denti-alveolar emphatic " $\mathrm{s}$ " is changed to voiced denti-alveolar "z". For example, they say, "tazdeer" ('export') instead of "tasdeer" and "azdartu" ('I issued') instead of "asdartu". In many modern Arabic dialects, this alteration between " $s$ " and " $z$ " is very common.

According to Muhsin (1978), the Fazara and Qais old Arab tribes change the long "a" into "j" in their dialect. It is said "fatj" ("boy') instead of "fata". The tribe of Tameem also make a kind of substitution when they say, "af?'” ('a snake') instead of "af?a", pronouncing the glottal stop of "hamza" to a long "a". This substitution is made since both "hamza" and "a" have the same 
point of articulation. AbdulTawab (1987) states that Classical Arabic does not belong to any particular tribe, but the product of various Arabic dialects. It has come into use because of communication among different Arab tribes during their pilgrimage, trading, literary gatherings and poetry competition.

Arabic dialects are characterized by distinct variation in the pronunciation of the uvular " $\mathrm{k}$ ": ' $\mathrm{q}$ ', ' $\mathrm{g}$ ' '" (Sallam, 1980).There is a number of these old dialects which have continued to be used in today's Arab world. First, al-Istinta: In this dialect, the letter sound of (' $\varepsilon$ ') "a'" _ glottal voiceless phoneme is alternated into nasal dental ( ' ن ") "n" as in the "anta" ('to give') instead of "a'ta". A certain reading of this verse from the Qur'an: "inna antinynaka al-Kawther" ('Indeed, We have granted you, [0 Muhammad], al-Kawther." ( [al-Kawther: a river in paradise] The Noble Qur'an, Sura 108: verse 1) instead of "inna a'?tiynaka al-Kawther." Another saying in Arabic: "la man'a lema antiyet wa la muantiya lem mana't" ('What Allah has given you can't be stopped and what is prevented can't be given" instead of "la man'a lema a'?tiyet wa la mu'?tiya lema man'?t" (AbdelTawab, 1999, 121). This Old dialect that was spoken by Old Arab tribes such as Sa'ad bin Bakr, Hudhail, Al-Azd, Qais, and Al-Ansar is still used in Yemen, Iraq, parts of Jordan and some villages around Nablus in Palestine.

Second, al-Kashkashah and al-Kaskasah: In this dialect, the letter sound of plosive voiceless velar (ك' ) "k" is substituted with ("ش' ) "sh" _ffricative voiceless dental as in "ja'la Allaho albarakah fe daresh" ('May Allah bless your home') instead of "ja' la Allaho al-brakah fe darek." Another example when one says in Haj: "labaish allahuma labaish" (I'm committed to your [Allah's] obedience'] instead of "labaik allahuma labaik." Arabic was localized among the tribes of Arabia. This dialect was among the tribes of Rabe'ah, Mudher, Bakr, Tameem and Assad. When speaking to a feminine in Tameem's dialect, they say: "ma alladhi ja' besh?" ('What are you up to?') instead of "ma allmadhi ja beck?" Another use of "alaish" ('upon you') instead of "alaik". al-Tha'albi (1938) mentions that Arabic speakers read a verse in the Qur'an in their dialect; they read, "gad ja'la rubbish tahtesh sarriya" ('Your Lord has provided beneath you a stream' Sura 19, verse 24) instead of "gad ja'la rubbiki tahteki sarriya." It was common among the tribe of Tameem to add the letter sound of "sh", this fricative voiceless dental instead of feminine "k". For example, they say: "e-laysha" ('to you') and "beshe" ('with you') instead of "elayka" and "beka". This dialect is used today among Arab speakers in Kuwait and Hathermoat of Yemen. Moreover, al-Kashkasha is found at Ahl al-Nummass and the areas around where they switch the " $\mathrm{k}$ " into a combination of " $\mathrm{t}$ " and "sh" or what is found in Kuwait today in their usage of " $k$ " in feminine addressee and the original " $k$ " in some words. Another example of the philological phenomenon of al-Kashkasha is found in Sohar Oman, where the word "halik" ('your condition' for feminine addressee') is pronounced "halish".

Regarding al-Kaskasah, this dialect was spoken by the tribes of Rabe'h, Mudher, O'zai, Bakr, Hawazen and Tamem. In this dialect, they change the letter sound of the addressee ('ك' ), " $k$ " voiceless velar into a voiceless dental (" $"$ '), "s" as in "daress" ('your house') instead of "darek". Other examples include saying "a'-laysh" ('upon you'), "mensh" ('from you'), "abous" ('your father'), and "ummas" ('your mother') instead of "a'-layka", "menka", "abouk" and "ummak". Certain speeches combine the "k" sound with "sh" or " $s$ ". It is said, "a'laykesh" and "a'laykes" ('upon you') instead of "a'layka". What is happening here, according to AbdelTawab (1987), is the changing of the " $\mathrm{k}$ " in al-Kaskasah to two-letter sound, " $\mathrm{k}$ " and " $\mathrm{s}$ " producing "kss" similar to the German word "Leipzig" -- the 'p' and ' $z$ ' combined to form 'pz' -- and in the al-Kashkashah, the change of two-letter sound of " $k$ " and "sh" producing "ksh" similar to what 
is found in the English word "Children" - the 'c' is combined with ' $h$ '. This dialect is common among the people of the Eastern part of Saudi Arabia in al-Qaseem and Beeshah.

Third, at-Tumtamaniyyah: In this dialect, the definite article, "al" ('the') is changed to "am". Some Yemeni tribes as al-Azd and Dous have used this alteration of the lateral dental 'l' to nasal bilabial ' $m$ '. Linguists refer this dialect to the Yemni tribe of Ta' $i$, who emigrated to the northern of Arabia. A poet of Ta'i says: he shoots with "am sahm", (with the arrow) instead of "as-sahm". Another poet of Zoubaid says: “ . . . am saif am salam”, ('the sharpened sword') instead of "as-saif al-salam". Other examples in this dialect include saying: "tab am hawa"” ("The air became fresh') and "safa am jawo" ('The weather became nice') instead of "tab alhawa'" and "safa' al-jawo". A Prophet's hadith says: "laisa men al-birr as-seyyam fe as-safer" ('It is not of the Lord's obedience to fast when traveling over 81 kilometers'). This hadith is read in the Tutamaniyyah dialect as: "laisa men am birr am seyyam fe am safer." The use of "am' as a definite article instead of "al' applies to nouns in this dialect such as "am enab" ('the grape') and "am hamat" (the fig) instead of "al-enab" and "al-hamat". This dialect is used in Sa'ba and other tribes of Yemen. Linguists refer this dialect to the old tribe of Himyar of Yemen. The use of "am hamat" instead of "al-hamat" ('the fig') is also used in Karak and the areas around it in southern Jordan whereas other parts of Jordan refer to the fig as "teen" not "hamat". This makes it clear that this old dialect is still in use in the Arab world in Sohar, Sa'ada of Oman, Yemen, Kuwait, Jordan and Arabia.

Fourth, al-A'ja'jeh: In the dialect of Qudha'h tribe, they substitute the emphatic " " ('ya') with "ج " ('j'). For example, “Tameemi” ('Someone form Tameem tribe') becomes “Tameemj”, "Abu Ali" (Name of a Person') becomes "Abu Alj”, "hejati” ('my haj'), and "ya'teek bee” ('he'll bring me') become "hejatj" and "ya'teek bej". This phenomenon can be explained phonetically: the "j" and "ya" sounds can be produced by the use of the front of the tongue and the roof of the palate. Thus the "ya" sound can be obtained by narrowing these two organs whereas the "j" sound can be produced by closing them down. Other examples of this dialect include the substitution of the " $\mathrm{j}$ " with "ya": "shayarah" ('a tree') and "shayarat" ('trees') instead of "shajarah" and "shajarat". This dialect is spoken in the southern of Iraq where they say "da-ya'i" ('chickens') instead of "da-jaj". In the Gulf region, particularly in Kuwait, they say, "ana ya'i" ('I'm coming'), "lamma yeyei" (When he comes'), and "riyal" ('a man') instead of "ana ja'i", "lamma yejei" and "rijjal".6

Finally, al-A'naneh: In this dialect, the "“" , (" " ") the glottal character of hamzah ('it is produced by holding the breath and leaving it out from the bottom of the throat') is changed into a glottal " $\varepsilon "$ (“?'). It is said: "same'tu '?nna fulanan qala katha”, ('I heard Mr. X saying so and so') instead of "same'tu anna fulanan qala katha". In another example, "tahsabu '?nni naem," ('you think that I am sleepy') instead of "tahsabu 'anni naem." This " " hamzah has been added to the beginning, the middle or the end of the word. Speakers of this dialect say: " "?nn" instead of " 'an" as in the word "innaka" ('you are') and "aslama" ('became a Muslim') changing into "'?nnaka" and "?slama" (Ibn Faris, 1910, I, 8). Other speakers say, "al", ("he said'), "'alat" ('she said'), and "ba'arah" ('a cow') instead of "qa'l", "'qalat" and "baqarah". This change of hamzah" " " occurs in the middle of the words such as "as-s'?f" and "as-s'af" ('ceiling') instead of "as-saqf". This dialect is nowadays very common among many people of Egypt, Syria, Lebanon, Palestine and Jordan. The hamzah is also found at the end of the words such as "al-kut?ah" and "al-kut'ah ('bucket for water') and "tak'?k'?" ('retreated') instead of "tak'aka". This dialect was common among Tameem, Qais, Qudha'ah and all other old Arab tribes surrounding them. This dialect nowadays is among the bedouins in Jordan and in Egypt and in 
some parts of Sudan. They say: "es'?l' and s'?ly" ('ask a question') and "al-Jur'an" ('The Qur'an') instead of "es'al' and 'sa'l" and "al-Qur'an". In the southern part of Egypt, this dialect is also used today among the people. For example, they say: "l'?" and "sa'?l" as alterations of "la" and "sa'al". This change is also found in northern part of Ethiopia, a Semitic language called "Teejaniyeh". They say: "sab'?" ('the early morning breeze') and "'?rba'?" ('four') as alterations of "saba" and "arb'a". These kinds of alterations could be explainable in the sense that the production of both these sounds, "?" and " " " are from the same place of articulation.

\section{CONCLUSION}

The Arab tribes of Arabia used to speak different dialects. These old dialects are related to the Classical Arabic, the language of The Qur'an. Classical Arabic continued to be spoken among the Arab world. Of course, the dialect of Quraish has been considered the most elevated one among the tribes of Arabia. Modern dialects are rooted in these old Arabic ones. Arabic language has been borrowing some vocabulary from other languages. It is an evidence of the richness of Arabic language with its linguistic terms that make it a living. Arabic language is rich in its dialects and linguistic terms. It is the language of the Qur'an. Old Arabic dialects taught as history are still be used and alive until today. Today's Arabic dialects have their bases and origins in the old dialects of Arabic. In other words, old Arabic dialects continue to exist in modern dialects although many speakers of Arabic are unaware of it. These findings are of value for those interested in Arabic dialectology.

\section{NOTES}

- On the history of Arabic dialects, see Jonathan Owens (2003).

- On the aspects of diversification in the linguistic structure of old bedouin and sedentary dialects of the 7th and 8th century centuries AD, see Fredric J. Cadora. (1989).

- On languages in the pre-Islamic period, see A. F. Beeston, (1981).

- For more on sound change in Classical Arabic consonants to comply with the way they are used in different Arabic dialects, see Anis I. (1990).

- Watson, J. C. (2007) discusses the dialectical differences and similarities of Arabic besides the phonology and morphology of Arabic.

- For more on Arabic dialects in the Gulf countries and how dialects have preserved certain "conservative" features that are similar to Classical Arabic, see Clive Holes (2001).

\section{REFERENCES}

Al-Seyyuti, Jalal Ed-Din. (1998) Al-Mezher fe Oloum al-Qur'an. (Blooming in the Study of Qur'an). Beirut: Dar ElKutob El-Elmeyah.

AbdulTwab, R. (1987) Fusoul fi Fiqh al-Lughah al-Arabiyah. (Chapters in Arabic Philology). Cairo: Maktbat alKhanji.

Anis, I. (1990) al-Aswat al-Lughawyah (Linguistic Sounds).Cairo: Maktabat al-Anglo al-Masriyyah.

Beeston, A. F. (1981) Languages and Pre-Islamic Arabia. Arabica (Jun-Sept) 28: 178-86.

Belnap, R. Kirk and Haeri, N. (1997) Structural Arabic: Charles A. Ferguson's Papers, 1954-1994. Leiden: Brill.

Brocklemann, C. (1916) Semitische Sprachwissenschaft. Berlin: Leipzig.

Cadora, Fredric J. (1976) Lexical Relationship among Arabic Dialects and the Sawdesh List. Anthropological Linguistics 18: 237-260

. (1989) Linguistic Change and the Bedouin-Sedentary Dichotomy in Old Arabic Dialects.

Anthropological Linguistics. (Winter-Fall) 31 (3/4): 264-284. 
Daniels, Peter T. Brights, W. Eds. (1996) The World's Writing System. New York: Oxford UP.

Donner, Fred M. (1981) The Early Islamic Conquest. Princeton: Princeton UP.

Ferguson, C. (1959) The Arabic Koine. Language. (Oct.-Dec.), 35 (4): 616-630.

. Myths about Arabic. In Structuralist Studies in Arabic Linguistics: Charles A. Ferguson's Papers, 1954-1994. Ed. R. Kirk Belnap and Niloofar Haeri. Leiden: Brill. 250-256.

Fischer, W. (1997) Classical Arabic. In The Semitic Languages, ed. R. Hetzon, 187-219. London: Routledge.

Habash, Nizar Y. (2010) Introduction to Arabic Natural Language Processing San Rafael: Morgan and Claypool Pub.

Holes, C. (2001) The Arabic Dialects of Arabia. Proceedings of the Seminar on Arabic Studies. London: 21-23 July 2005: 25-34.

Khrisat, Abdulhafeth and Majiduddin Sayyed Mohamad. (2014). Language's Borrowings: The Role of the Borrowed and Arabized Words in Enriching Arabic Language". American Journal of Humanities and Social Sciences. 2 (2): 133-142.

Muhsin, Mahdi S. (1978). al-Muqtabas min al-Lughah al-Arabiyah wal Qur'aniyah. (Selections from Arabic and Qur'anic Dialects. First Edition. Cairo.

The Noble Qur'an. http://quran.com

Owens, J. (2003). Arabic Dialects History and Historical Linguistic Mythology. Journal of American and Oriental Society 123 (4): 715-40.

Sallam, Atef. (1980) Phonological Variation in Educated Spoken Arabic: A Study of the Uvular and Related Plosive. Bulletin of the School of Oriental Studies, 43 (1): 77-100.

Seebawaih, Amer bin Qamer. (1977) Al-Kitab: Kitab Sibawayh (The Book: Seebawaih’s Book) Revised by Harun, A. M. Vol. I. Cairo: Matb'at Qanaji.

Versteegh, K. (1997) The Arabic Language. Edinburgh: Edinburgh UP.

Watson, Janet C. E. (2007) Phonology and Morphology of Arabic. Oxford: Oxford UP.

Woodard, Roger D. (2008) Ancient Languages of Syria, Palestine and Arabia. Cambridge: Cambridge UP. 